\title{
Structured methods of data production and their visualization using GIS: semantic domains in ethnographic research of landscapes
}

Strukturyzowane metody wytwarzania $i$ wizualizacji danych z wykorzystaniem GIS: domeny semantyczne w etnograficznych badaniach krajobrazów

\section{Introduction}

A landscape is a complex system of natural, social and cultural processes affecting social ties, shared identity as well as culture. Social structures, knowledge and experience are projected into space, which reflects back on them. The material and social context of a landscape is complementary as well as synergistic, therefore, it is appropriate to study a landscape in an interdisciplinary manner using various techniques, methods and tools of ethnographic research. 
In a narrower sense, we can perceive a landscape as a collection of various places that appear and are categorized in ethnographic research in the present as well as the remembered world of those who tell its stories. Categorization is present in all human perception. It is categorization and classification that mediate and process our experience. Through categories, we perceive, understand and organize our individual, social and physical space. Categories are defined by our joint conclusions about the similarity of things, their qualities and similar experiences (Lakoff 1990: 19). If we want to know how people think about the landscape that surrounds them, how they perceive it, how they divide the various places in it, and how they orient themselves in it, structured methods of data collection based primarily on the analysis of semantic domains can help us generate the required data. ${ }^{1}$ In order to better understand such data and at the same time present them in a user-friendly format, it is desirable to try to visualize the obtained results².

In ethnographic research, we produce data that can have certain spatial characteristics; they can be localized and further processed using various Geographic Information Systems (hereinafter GIS) tools. Ethnographic data contain, whether intentionally or unintentionally, information that refers to specific locations, places or areas in the terrain, and the various items of the semantic domain related to the landscape can thus be presented in the form of a map. We treat maps and visualization through them as researchers' tools for understanding space and tools for encoding the actors' image of the world. The maps in our research are fully created by researchers based on actors' descriptions and categories, so they are more visualization tools than intellectual technology (in terms of Nicholas Carr 2010).

In this article, we will present how, using the example of research studies connected with the perception of a landscape, some structured methods of data production used primarily in cognitive anthropology ${ }^{3}$ can be applied along with the possibilities of data analysis visualization using geographic information systems ${ }^{4}$. We will show the process of working with data gained by qualitative techniques and transferred, using semantic domain analysis, to the GIS interface, and will outline the room for

1 In this context, we deliberately present methods of "data production", because part of the researcher's personality, their knowledge, methodological and theoretical background are so significant in anthropological research (or, more precisely, so critically reflected compared to other scientific disciplines) that we cannot speak of mere data "acquisition" or "collection". As we like to tell our students: "Data are not like raspberries, hanging from a branch. Data come into existence in our hands; it is an active process" (Toušek 2012).

2 The text is based on two previously published science popularization texts: 1) G. Fatková, Data v antropologii I.: Strukturované metody vytvárení dat (Fatková 2015); 2) T. Šlehoferová, Antropologická data v prostředí Anthropac a GIS (Šlehoferová 2015).

3 The processing of data using the concept of cultural or semantic domains is conducted in the free Anthropac software application (Analytic technologies).

4 In this case, the data were processed using the ArcMap 10 software. 
interpretation opened up by such a multi-level approach using various tools. Although we subjected the described procedures to pilot verification in our own research, the connection of the presented methodological approaches is still open to scientific discussion and mainly further experimentation.

\section{The study of semantic domains and the analysis of a cultural consensus}

Structured techniques differ from unstructured ones in that they acquire data from informants based on them completing a "task" which usually does not take long, and are thus much less time-consuming than unstructured techniques. However, it cannot be said that data generated this way are of better quality; it is always desirable to have these two types of techniques complement each other in research When the focus of our interest is on a landscape and spatial aspects of culture, in a short amount of time structured methods can provide us with a solid set of data most often bearing witness to the actors' perception of space, the significance of the various spatial components as interpreted by the actors, and lastly also to the degree of agreement between actors and the diversity of their knowledge of space or spatial processes. On top of that, informants usually enjoy engaging in these techniques, as they take on the form of a kind of children's game and make them think about ordinary questions using interactive tasks.

Susan Weller considers structured interviewing a technique which in research design comes second after unstructured mapping of relevant topics and domains (Weller 2014: 353). The majority of the techniques analyzed below are based on the concept of semantic (or also cultural) domains. When analyzing semantic domains we are interested in how people in a group think about phenomena which from an emic perspective they classify as belonging together or being similar, i.e., what are the domains with the help of which they classify the world, what entities fall under them, and to what extent people agree on this mainstream division. Domains may include all sorts of things: a group of elements that are tangible and observable (such as trees, animals, medicinal plants, edible crops, places in a landscape, etc.) or a purely conceptual set of elements (such as occupations, emotions, activities, relational terms, properties, causes, transitions, etc.). Methods mapping these domains were elaborated mainly in the field of cognitive anthropology and subsequently also applied to areas such as market research or medicinal anthropology. As the human mind to a certain extent classifies all spheres indiscriminately, this field of view can also be used in the study of space and landscape, particularly if we follow on from the studies of psychologizing geographers striving to capture the actors' perception (Fagerholm et al. 2020; Komossa et al. 2020)

The technique of freelisting and classification techniques can help us determine not only what items belong to a domain, but also reveal the domain's structure 
and the relative significance of the various elements within a domain. The ideal follow-up technique is cultural consensus analysis, which additionally tells us to what extent informants agree on the composition and classification of a domain. We can thus discover a consensus area, but also any variability within a group. It can reveal the so-called community experts on the given problem or semantic outsiders. Cultural consensus analysis can also serve as an ex-post check of the task we have formulated and the coherence of the observed population. The combination of freelisting and classification techniques is sufficiently described and applied in other texts (Borgatti 1994; Weller 1998; Bernard 2000; Gravlee 2005; Weller 2007), much more so in the so-called "ethnoscience" fields which developed under the heading of cognitive anthropology and is connected mainly with the wave of the so-called "New Ethnography".

Apart from data on the various domain items, the technique of freelisting can also tell us much about the cohort of informants itself. This set of formalized techniques is called "the cultural consensus model" (Romney et al. 1986) or "the cultural competence model" (D'Andrade 1995) and maps out the competencies of informants in terms of their knowledge of the semantic domain. Weller and Romney (1988) further dealt with the question of how many informants we need to acquire valid and reliable data from structured interviews. $99 \%$ of data on a semantic domain is provided by as few as ten informants with an average cultural consensus competence index of 0.7, which is a very realistic situation if we choose the question and the sample well. The size of the sample obviously also depends on how general or specific the posed questions are (for details, refer to Fatková 2014).

\section{Freelisting}

The method of freelisting is used for a general mapping of a domain (delimiting its contents and the inner hierarchy of its elements). By way of subsequent cultural consensus analysis, we can ascertain to what extent knowledge of a cultural domain is shared and how deep this knowledge is among the various informants. Using this simple technique, it is possible to generate data on the individual listed items as well as on the people who have listed them (Quinlan 2005: 7). When using this technique, we ask our informants to name all the elements of the given domain, for example, "List all the places in your surrounding area that you associate with your childhood. Any places that you remember."

Ideal for these purposes are domains consisting of categories that are easy to express verbally, that is, domains whose contents are part of the informants' active vocabulary (Quinlan 2005: 3). Another thing that is ideal for further processing is if the individual domain elements can be expressed using a single word. If a domain is made up of phrases, the researcher will need to go through the difficult task of 
standardizing individual phrases that in different informants' formulations can refer to one concept (Weller and Romney 1988: 15).

Quinlan (2005) identified three premises that this method is based on:

1. The sequence of the listed items reflects their level of importance, familiarity or prototypicality in the given domain (items listed earlier are more central within the domain).

2. The degree of knowledge of a domain is individual. Individuals with profound knowledge of the researched domain list more items than those who are less familiar with it.

3. Items in a domain are generally locally specific (a tree domain will be dominated by coniferous trees in a cold climate, but in warmer areas citrus trees will dominate).

The freelisting method has a number of advantages. It is fast, quantifiable, but at the same time is a good springboard for qualitative research. Despite its extreme simplicity, it is capable of collecting data from a large sample of informants in a short period of time. The advantage of this technique is that it does not require prior expertise in the particular domain on the part of the researcher, and is suitable for the initial stage of research in a new environment (Quinlan 2005 3-4). This technique makes accessible the applied emic concepts in the context of other emic concepts.

The freelisting method can be applied either in writing (when we get the informant to make a list of items) or orally (a task is given and the interviewer writes down the list of items). The interview should always be conducted in the form of tasks: "List all the XY (e.g., nearby villages, points of interest in the surrounding area, etc.)". The answer should ideally exhaust the informant's knowledge of the given domain, i.e., they should list all the items of the given domain that they know, which they commonly use, or which are considered part of the domain (depending on the formulation of the research problem).

Devon D.Brewer (2002) offers several techniques for prompting informants in the event that they cannot remember any item in a domain. The first one is a non-specific prompt consisting of a question like: "What other items can be found in XY?". Another technique is going over the list. If the list is not written by the informants themselves and they cannot see it in front of them, we can read it to them so they know which items have already been listed. Reading the list can cause associations with other, unlisted items. The last technique is the use of the listed items as a stimulus for others (e.g., You have mentioned forest management. Can you think of anything else in the domain of entities transforming the surrounding landscape?). In another publication, Brewer et al. (2002) add another two similar techniques, so-called redundant questioning, which consists in repeating the question in other words, and probing for an answer using an alphabetical stimulus, i.e., 
going through the individual letters of the alphabet with the motivation that the letter might cause another association (e.g., Can you think of any such entity which starts with the letter " $C$ "?).

Freelisting can be used in research on a one-time basis to map a domain, or researchers may use the method of successive/multiple freelisting, which consists in several steps of listing joined in one interview. This is usually used for mapping the organization of various sub-categories within one domain and it can also map domains in immediate semantic proximity (Ryan et al. 2000).

\section{Classification study}

Classification study is a term used by Susan Weller (2014). Tasks given to informants are based on the elimination (triads) or pilesorting of items in a domain. The following three techniques are most commonly used in classification studies: a) paired comparisons, b) triad tests (triads), or pilesorting. In paired comparisons, we work with a list of pairs and ask respondents to circle the item in each pair which better corresponds to the set criterion (e.g., "In each pair, circle the word that in your view better fits in the sphere of nature" or "do you feel safer in place $X$ or $Y$ ?"). In the triad technique, we also start with a list of entities that are combined into original triads (e.g., the Anthropac software can generate a questionnaire with triads). We ask respondents to cross out the item in each triad that least fits in the group. Unlike paired comparisons, there is no need to set an external criterion and the informant evaluates the various items based solely on their similarity/dissimilarity or connection or lack thereof.

In the pilesorting technique, respondents sort a set of cards (with words or images) or objects whose classification we want to determine. Each card or object must be numbered for the sake of record keeping in the Anthropac software application. The respondent sorts the cards (or physical objects) based on their similarity, either on a one-time basis (free pile sorts) or in multiple steps (multiple pile sorts) (Bernard 2000: 272). For certain types of research problems, so-called successive pilesorting is used. After the initial sorting, we ask respondents to further sort each pile based on more detailed classification principles (discussed further in Boster 1994).

The methods of paired comparison and even more so the method of triad tests are intended for small sets of items. The advantage of these two techniques is their similarity to the type of tasks which we are used to from school. Informants do not usually hesitate and immediately complete the task, which they find clear and easy to understand. The pilesorting method is less understandable for respondents and the undefined division criteria can surprise them. Unless it is a domain which a respondent is used to thinking about analytically, they find the task of sorting cards or items very vague. 
Working with data in Anthropac software ${ }^{5}$

Data produced based on the analysis model of so-called semantic domains can be processed using the Anthropac software application developed by Stephen P. Borgatti ${ }^{6}$ Freelisted data may also be processed using the add-in for Microsoft Excel (FLAME) (Borgatti 2015). Although we will present data produced with the freelisting method, we will stick to using the Anthropac software, which from the point of view of modern technologies is an outdated application of the MS-DOS type; however, we could not do without it if we wanted to expand the research by additional classification study techniques. In this sense, the Anthropac software presents a unique tool applicable in ethnographic research for the analysis of semantic domains.

The set of field data can be imported in the form of a text file into the ANTHROPAC software and analyzed using the FreeList tool. The result of the import is a table showing the frequency of the various items (FREQUENCY), their frequency expressed as a percentage (RESP PCT), the average ranking of the term in the informants' statements (AVG RANK) and the Smith's index (Smith's S) - see the figure below.

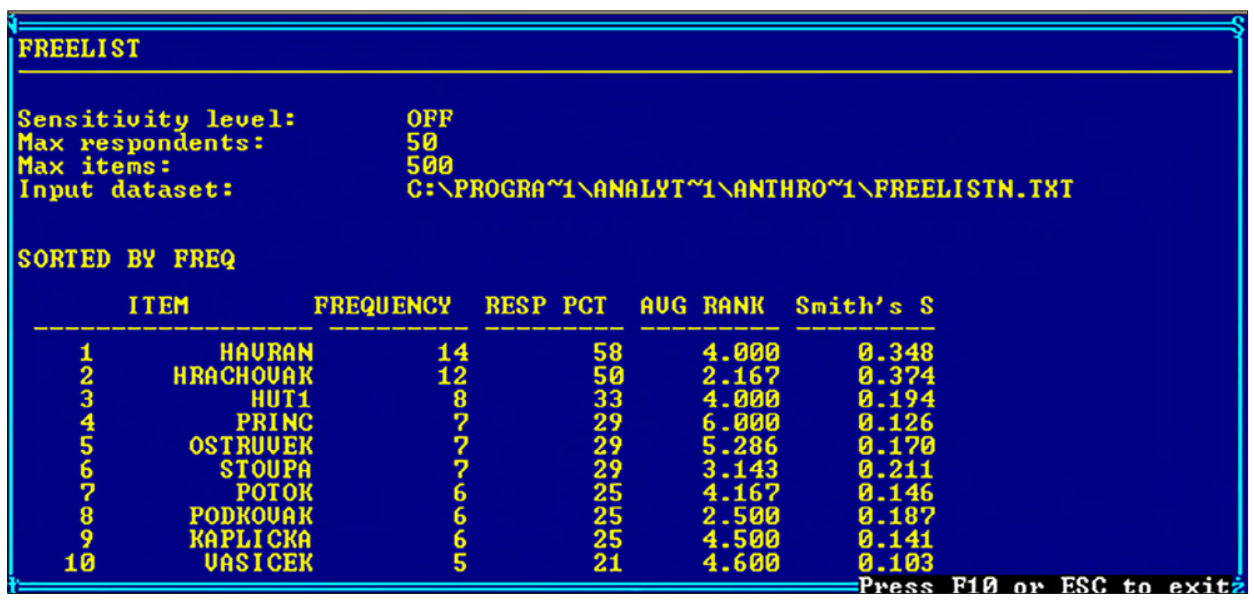

Fig. 1.

A view of data acquired from freelisting following their import into the ANTHROPAC software

5 A big thank you goes out to our colleague Dr. Daniel Sosna, who acquainted us with Anthropac, purchased its first version and subsequently trained several generations of students in how to work with this software. Thanks to him, a number of high-quality theses could come into existence, e.g., Anna Becková's master's thesis, in which the student created special software for creating similarity matrixes (Beckova 2015).

6 For more information about the program, refer to http://www.analytictech.com/anthropac/anthropac. $\mathrm{htm}$, where the various versions of the software are freely available for download. A comprehensible, detailed description of the basic use of the Anthropac software, including images for illustration is, apart from its creator's user guide, also available in the Cognitive Anthropology Lab Book (available from: http://bierdoctor.com/downloads/EmileeLabBook.pdf). 
An important output of the FreeList analysis is the frequency of each item mentioned by respondents. Another important indicator is the so-called Smith's saliency index, which expresses the significance of a particular item in the domain. This index takes into account the frequency of the given item in the respondents' narrative as well as the order in which the informant lists the places. Unlike mere frequency, it emphasizes the significance of items in the cultural domain and draws attention to items which subsequent analyses should focus on (Smith 1993). Data can be viewed and further processed (e.g., to identify informants who stand out in the observed population, or to prepare materials for the pilesorting method).

It is necessary to realize that in most domains, items that are mentioned only once cannot be included in the shared cultural domain. A cultural domain has a so-called core-periphery structure - a certain central set of items that were repeated by most informants and a peripheral set of items that were listed only by a few informants or a single one (Gravlee 1998). A set of individual items is interesting in and of itself; it corresponds to the knowledge of individual informants and also shows how familiar the informant is with the particular domain (e.g., in research into a landscape and its points of interest, the responses by informants actively engaged in hiking will include a much larger set of items, including less familiar places, than those of other informants).

As the theoretical concept of a cultural domain puts an emphasis on it being shared within the observed population, these rarely shared items need to be eliminated from further analyses. Using the ANTHROPAC software, it is possible to generate the so-called item by item similarity matrix, which is a table in which each of the listed items is related to each next listed item - this allows us to see how many times each item is found on the same list from a particular informant as another item, with the figure indicating the "similarity" between the two items, i.e., how many times these two words appear on the same list.

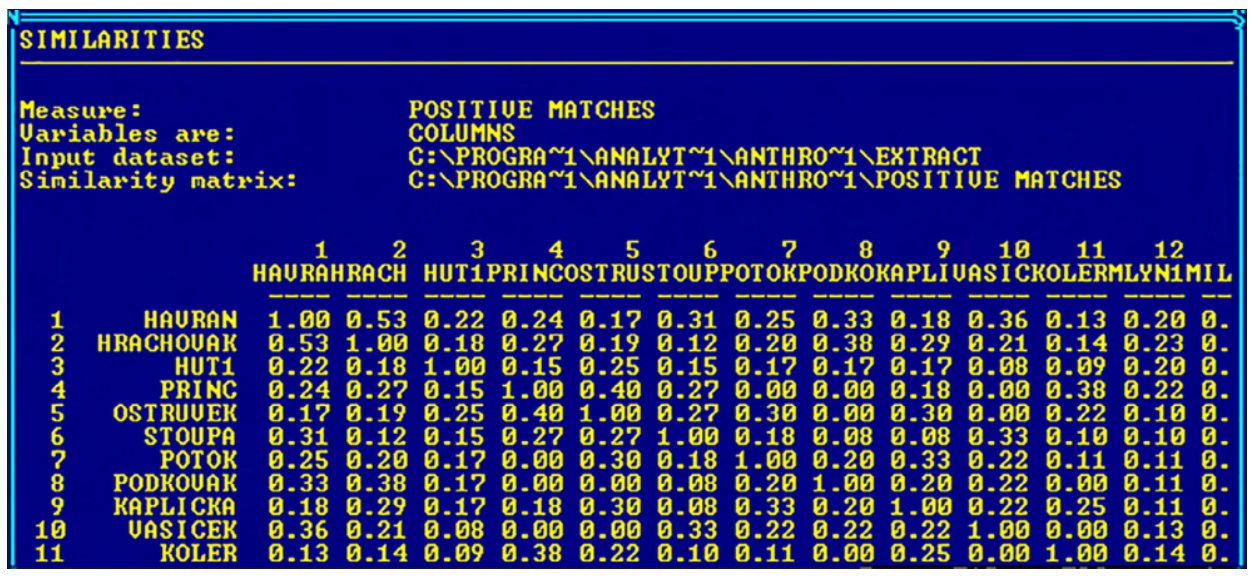

Fig. 2.

Similarity matrix in Anthropac 
This matrix can help us identify the core/periphery partition (Borgatti-Everett 2000), particularly if we use additional Anthropac tools - Multidimensional Scaling, which can help us visualize the item by item similarity matrix in a two-dimensional space, which often reveals the core-periphery structure.

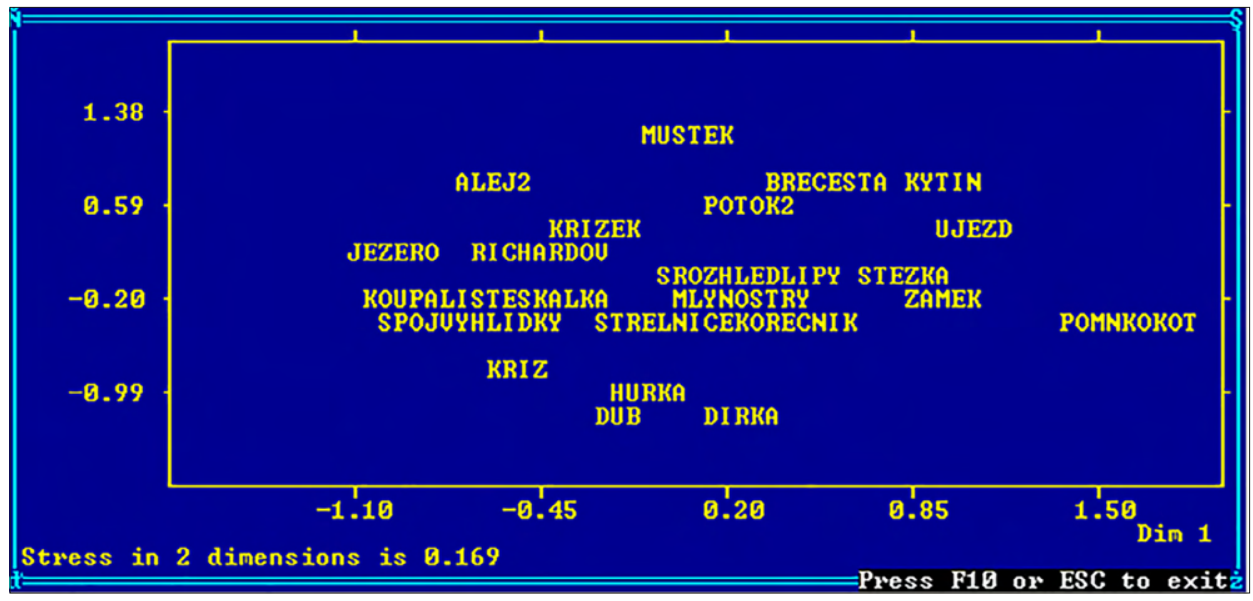

Fig. 3.

Visualization of data in a core-periphery structure

Anthropac is a unique and as far as we know the only available software application for processing complex analyses of cultural (or semantic) domains. However, one cannot expect its output to be of high graphic value. Moreover, this software has seen very little development since the 1980s. Since then, requirements in terms of the visual aspect of result presentation have significantly increased and researchers cannot avoid secondary processing of research results using another software application.

If individual elements of a domain refer to specific geographical places, the resulting data can be localized (e.g., using GPS coordinates), visualized and further processed. In our research, we imported the data into ArcMap 10 and worked on their spatial visualization, which would be difficult to achieve without formalized data collection.

\section{Semantic domain analysis, geographical information system and ethnography}

From the wide range of methods of data production for analyzing semantic domains, the most widely used and most commonly known is the technique of freelisting, which serves the purpose of initially mapping the contents of a conceptual field. The application of GIS technologies has also recently been adopted across scientific disciplines. GIS technologies are considered to be a very useful tool in mixed research design and are no longer limited to displaying quantitative data. In current landscape and spatial 
research bordering geography and ecology, the combination of freelisting and GIS has been successfully applied, for example, in a study by a team led by Nora Fagerholm (Fagerholm et al. 2020). However, in this case the results of freelisting were used only to complete the geographic context of data generation (i.e., what type of landscape the respondent lives in and how it affects his responses). Another example is Franziska Komossa and her team (Komossa et al. 2020), who aim to improve our understanding of how various methods differ in their capacity to capture data on outdoor recreationists' preferences. The authors applied both direct engagement methods in the form of interviews (incl. participatory mapping, freelisting and quantitative photo ranking) and indirect engagement methods (incl. analyzing social media content). Two of the methods applied to gather information on landscape preferences, namely freelisting and social media user tags, were able to capture attributes related to the social and cultural appreciation of landscapes, including sensory qualities of a landscape or sense of place. But freelisted data depict higher term frequencies in this category compared to social media photos and user tags (Komossa et al. 2020: 7-8). Both studies draw inspiration directly from cognitive psychology (not from anthropology, where specialized software has been developed to process data generated using these methods). In ecology and geography, the method of freelisting has been used since 2014 (Bieling 2014) and has so far maintained its popularity.

The method of freelisting is also commonly used in applied archeology (Balée, Nolan 2019) and human ecology (Stara et al. 2015). Using the technique of freelisting, Balée and Nolan (2019) are trying, for example, to determine the possible location of archeological sites in the Amazon's virgin forest. The spontaneous recognition of species in different landscapes by the use of freelisting is indicative of traditional knowledge and its potential implication for the identification of archeological sites (Balée, Nolan 2019: 372). Wartman engages in a more general reflection on categories in which we understand space (Wartman et al. 2015). Using the method of freelisting applied to an open landscape, the semantic domain is mapped with the question: 'What is there for you in a landscape?' Another field which often applies the method of cultural domain analysis is food studies (e.g., Sorts 2017).

Within complex mixed research design, the method of freelisting along with GIS processing of spatial data is also found in medical research. For example, an interdisciplinary team from Pennsylvania, USA (Keddem et al. 2015) uses this combination in their research of asthma. They treat asthma as cofluenced by environmental factors. Their aim was to understand neighborhood influences on asthma control in a low-income, urban community and describe findings that blend responses to participant interviews with geospatial analyses. In their research, the authors refer to the development of the theory of semantic domains and the methods of their analysis in anthropology and, like us, use the Anthropac software to process the results. What makes this research interesting is that the data acquired using the freelisting method 
were, just as in the research presented in this article, further stratified according to demographic characteristics. The researchers wondered whether the definition of a domain will vary between the various age groups. Based on topics arising from the freelisting data analysis, urban space data were sought, particularly regarding vacant properties, illegal dumping, parks, tree canopy, aggravated assaults, and theft In terms of the risk of asthma, suburbs with a risk of an increased incidence of this condition (parts of town with high population and vegetation density, or those with an increased crime rate) were identified. GIS tools were used not only for visualization, but also for modeling the intensity of various spatial characteristics with respect to the risk of asthma.

The connection between GIS and ethnography can be referred to using the special term "geo-ethnography" (Matthews, Detwiler, Burton 2006). This term refers to the fact that data containing certain spatial characteristics are naturally encountered in various ethnographic research studies and their data analysis and interpretation may take advantage of possibilities offered by GIS. GIS can prove itself useful in any type of anthropological research where the research problem has a spatial dimension, with "space" being de facto an integral part of every individual or society as such. GIS can be used not only in theoretical anthropology, but also provides tools applicable for practical purposes.

GIS can be used for mapping a territory from the perspective of the actors living there; for example, specifying places used for acquiring sustenance (hunting grounds, laying traps, fishing spots, places where crops are collected, etc.), while these types of data can, among other things, be used for practical purposes, including local natural resource planning, community planning, integration of traditional knowledge in the process of tribal decision-making, etc. (Mac Chapin et al. 2005). Another possibility of applying GIS is the research of urban areas, for example, research focused on the observation of spatial changes in the crime rate in the border region of Öresund, Denmark, and Malmö, Sweden, in 1998-2001 in connection with the opening of a bridge in July 2000 connecting Copenhagen and Malmö. GIS-assisted mapping revealed the importance of the new bridge in smugglers' routes as well as the changes in spatial distribution of crimes committed (e.g., as a result of the increase in the number of cars parked in the vicinity of the bridge, there was a rise in car thefts, and there was a change in the places with the highest number of sexual harassment cases, public order offences and personal theft cases, etc.) (Ceccato, Haining 2004).

GIS can also be applied in research in which data are collected using a variety of structured and localized mental maps. One such example is research into the creative potential of the city of Darwin and its connection with other urban space characteristics. Informants, i.e., those who made a living by creative activities (actor, director, architect, artist, designer, choreographer, curator, dancer, filmmaker, producer, musician, photographer, tattoo artist, and others) were given basic ("blank") maps, 
in which they indicated their responses, which could subsequently be georeferenced. The informants' responses led, among other things, to the creation of a map of creative inspiration which depicted the answer to the question: Where do you go in search of creative inspiration? This innovative way of processing data was used not only for the analytical stage of the research, but also as the basis for presenting research results to groups of stakeholders (Brennan-Horley, Luckman, Gibson, Willoughby-Smith 2010).

The application of these techniques and methods in our research is thus not innovative in the use of freelisting or GIS, but in their specific joint application. Similar to Shimrit Keddem (Keddem et al. 2015), we would like soft qualitative data to be the foundation for creating visual outputs, such as maps. We consider qualitative data a significant part of all data produced and in line with the cultural anthropology tradition we cannot imagine research without them. At the same time, we want to present the map not only as a tool for presenting results, but also as a tool to analyze and reflect on them. This creates room for interdisciplinary cooperation (particularly with fields such as geography and ecology, which so far have developed their research techniques independently of anthropology).

\section{Research into the distribution of important places in a landscape using the freelisting method and GIS tools}

Over the course of a 3-year project (2012-2014), our research team focused on the identification and presentation of forms of treating a landscape area that took place in the 20th century in the Pilsen Region in connection with political transformations, technological innovations and ways of spending free time?. Two rural locations of differing population and landscape configurations were chosen for the case studies (the more centrally located town of Bušovice, typical for the extensive agricultural use of its surrounding areas and its stable population, and the border town of Lesná, located in the forested border area, typical for its dynamic changes in population in the past half a century)

Researchers attempted to capture the domain of important places and localize the individual places on maps. To map the emic adoption of a landscape by covering it with places of significance, we utilized in-depth interviews as well as structured interviewing based on the formal model of semantic domain analysis, using the method of freelisting. The aim was to determine the contents and extent of the domain and the degree of consensus among the various participants. In the case of the border town of Lesná, we wanted to examine the common stereotype about post-WWII settlers,

7 This part is based on data generated within the project by the Department of Anthropology at the Faculty of Philosophy and Arts at the University of West Bohemia: "Settlement and landscape areas as a reflection of the cultural heritage and memory of a nation" (č. DF12P010VV008); for more information on the project, refer to http://www.antropologie.org/cs/sidelni-a-krajinny-prostor-jako-soucast-kulturniho-dedictvi-a-pameti-naroda. 
who are said to lack ties to the local countryside and respect for it. The informants were asked to list all the important places in the surrounding area ${ }^{8}$. The schematic map used during the interviews served mainly to elicit and facilitate informants' spatial orientation. Interviews also included the collection of sociodemographic data (age length of residence in the location, employment, gender, etc.). A total of 51 in-depth interviews were conducted (27 in Bušovice, 24 in Lesná). The freelisting method was used in an approx. one-hour in-depth semi-structured interview focused on the thematic areas of the individual's configuration of the sense of landscape, the memory and story of the landscape, negotiating the sense and decision-making processes in the landscape, public and private space and its perception at present and in the past. Apart from data regarding the cultural domain of important places, a large number of other types of data were also collected.

If we take a closer look at the selected data, we see that in the Lesná location informants listed a total of 57 different places in the categories of military structures, natural heritage sites, surrounding villages, former villages and homesteads, crosses, chapels, churches, castles and other structures (mill, memorial, stone cross, gamekeeper's lodge, and others), with 28 places specified for the purpose of defining the shared cultural domain (the first 10 of which are listed in Table

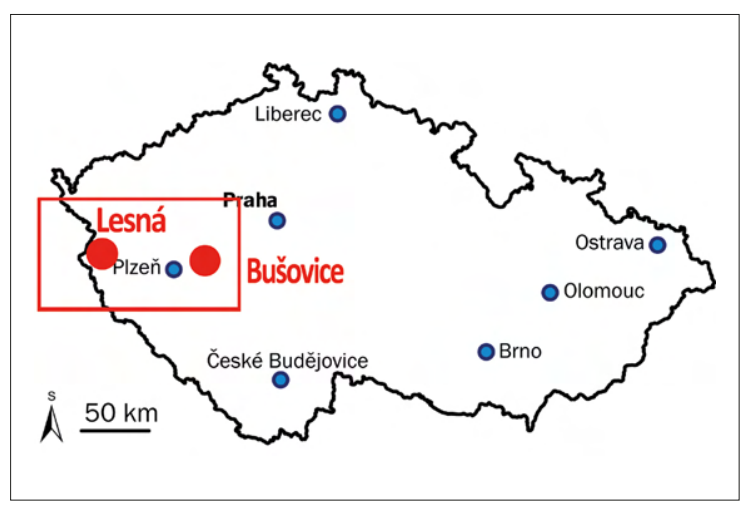

Fig. 4.

A localization of researched villages Lesná and Bušovice 1 below), i.e., places that were listed by at least two informants, while the remaining places were only mentioned by one informant. It is the places that were listed by more than one informant that can be considered places creating the core-periphery structure of a shared cultural domain, with the most frequently listed places found in the very core of the cultural domain (cp. Gravlee 1998). The collected data were synthesized using the Anthropac 4.0. software, the result being a list of the places ordered according to their salience (Smith's index), expressing not only their frequency, but also their so-called salience (the order in which they were listed by informants) 9 .

8 In most cases, the questions had to be specified as to what type of places the researchers were interested in ("places you like to go to", "places of personal significance to you", "places you associate with certain memories"). According to a recommendation by Brewer (2002), the informants' memory was stimulated using a recap of the places already listed and showing them on a schematic map, on which they were marked. In some cases, when the location was not clear, the locations were marked on the map by the informants themselves.

9 This paper will display described methodologies on data only from the border town Lesná. 


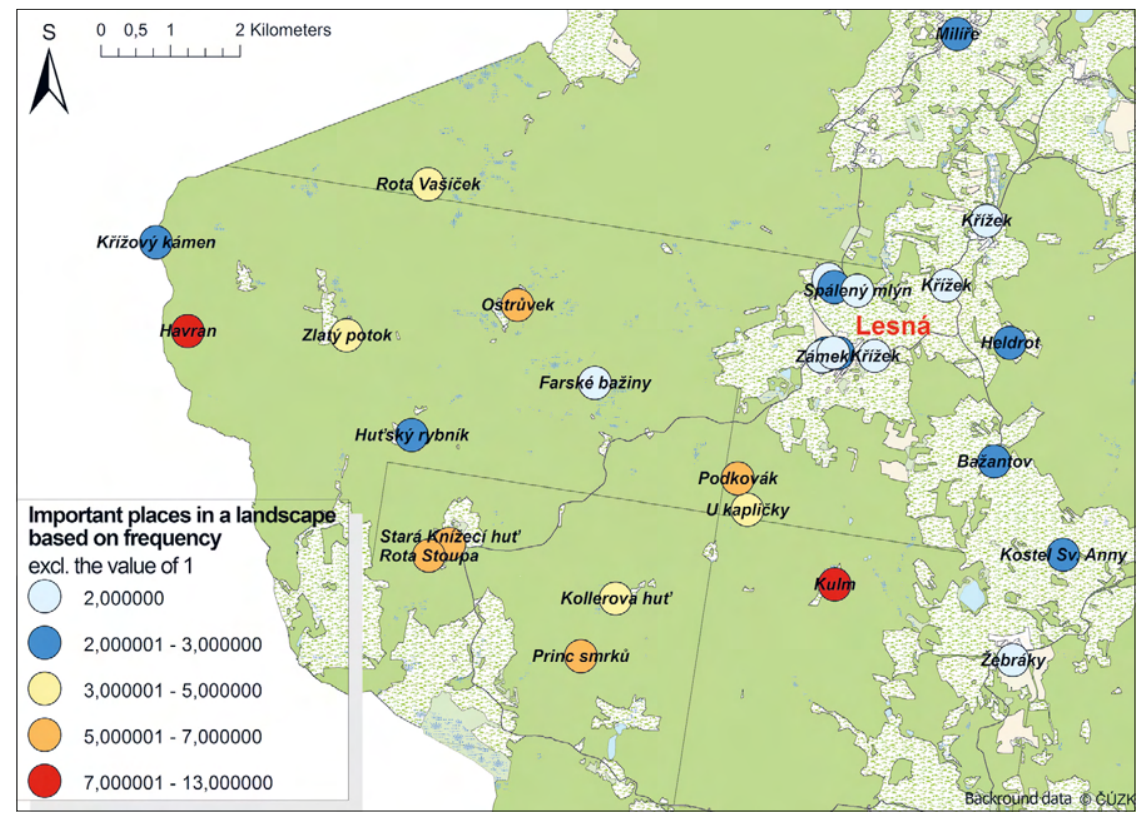

Fig. 5.

An example of a graphic representation of data - important places in a landscape based on frequency (excl. the value of 1 )

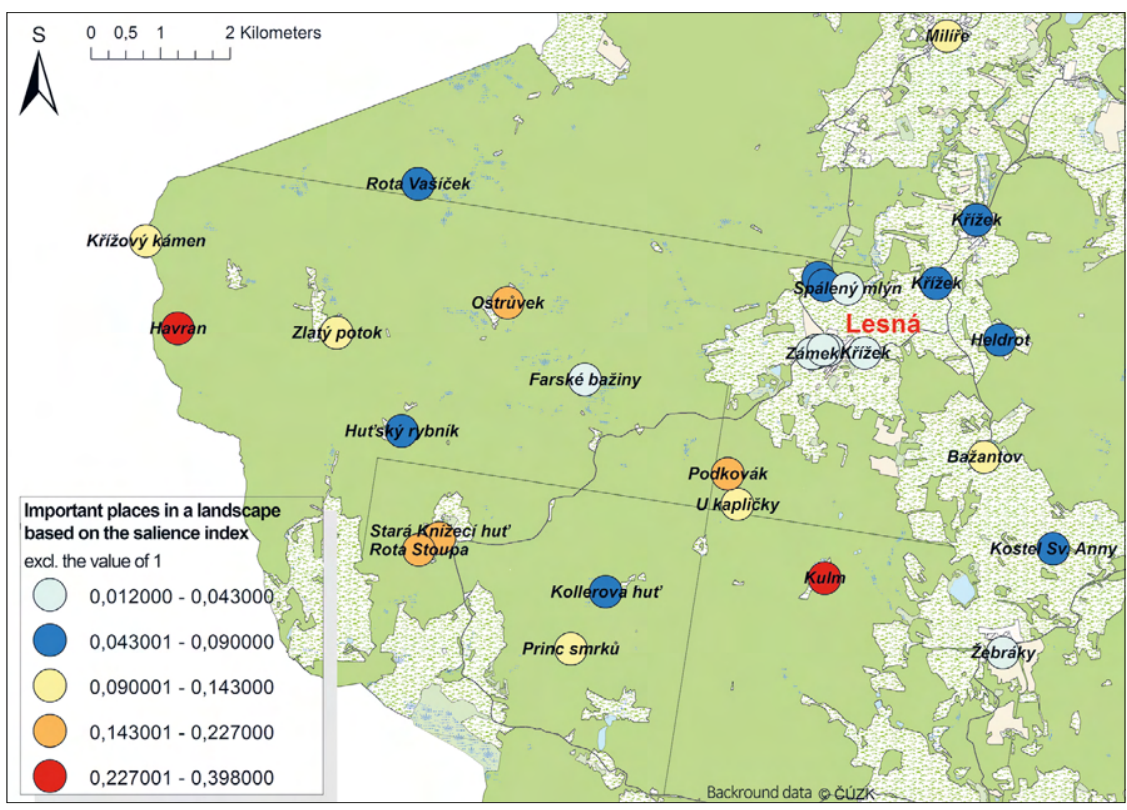

Fig. 6.

An example of a graphic representation of data - important places in a landscape based on the salience index (excl. the value of 1) 
The various elements of the semantic domain referred to spatial attributes, therefore, the formalized data could be localized (among others using GPS), visualized in ArcMap 10 and further analyzed. The individual elements (salient places) were depicted on a map based on their frequency (except for the value of 1), salience (the so-called Smith's index), and the distinction between the informants' attributes (e.g., male, female, senior, young, etc.). The result of this synthesis was a group of places of significance characterized by the informants' consensual agreement. This was followed by the interpretation stage, in which the formally defined semantic domain of places of significance was reflected on using data acquired through less formal techniques - particularly semi-structured interviews, informal interviews and guided tours with local residents.

The various studies connected with the research analyzed how individuals conceptualize the surrounding landscape based on the informants' selected attributes (e.g., according to gender - Fatková and Zíková 2014), or on the role of the studied population's religious affiliation in their relationship with the surrounding countryside (Bušovice - mostly non-religious, Lesná - mostly Eastern Orthodox Christians) and how the various places in the countryside are named and renamed within the process of discourse encounters (e.g., the post-WWII elimination of German toponyms - Fatková and Zíková 2013). In the presented research, the freelisting method helped lay out the conceptual field, in which researchers subsequently applied various more or less non-formalized methods of data collection.

Figure 6 represents important places from the perspective of research participants in the Lesná location and the surrounding area. The graphic representation of the data is based on Smith's salience index. In this respect, the most salient, collectively shared places are connected with border protection (the former Havran radar tower, the village of Stará Knížecí Hut', and the base of the Stoupa military company) or natural sites (fish pond and the remains of the former village of Kulm, a large spruce tree called The Prince of Spruce, or the Podkovák nature reserve). Places of medium significance are the current villages as well as the former villages and settlements that ceased to exist in connection with events following 1945 (Milíre with its church, Kollerova Hut', Žebráky, Heldrot, Bažantov), and also crosses, churches as well as pilgrimage sites (U kapličky, Church of St. Anne). The most significant collectively shared places are located in the strip of forest in the direction of the Czech-German border. The landscape to the west of Lesná in the direction of the town of Tachov is not exactly full of places of significance. The alleged absence of a bond with the countryside on the part of residents who moved to the border region after the war was not confirmed. Their salient places are located in the uninhabited border region, where their bond with the landscape does not spatially intersect with that of the old Czech residents. The difference between the old and the new residents in terms of their relationship to the landscape is apparent. The question remains to what extent the relationship of a relatively small number of new residents differs from that of the original, very large population of the German enclave that was driven out of the region after the war. 


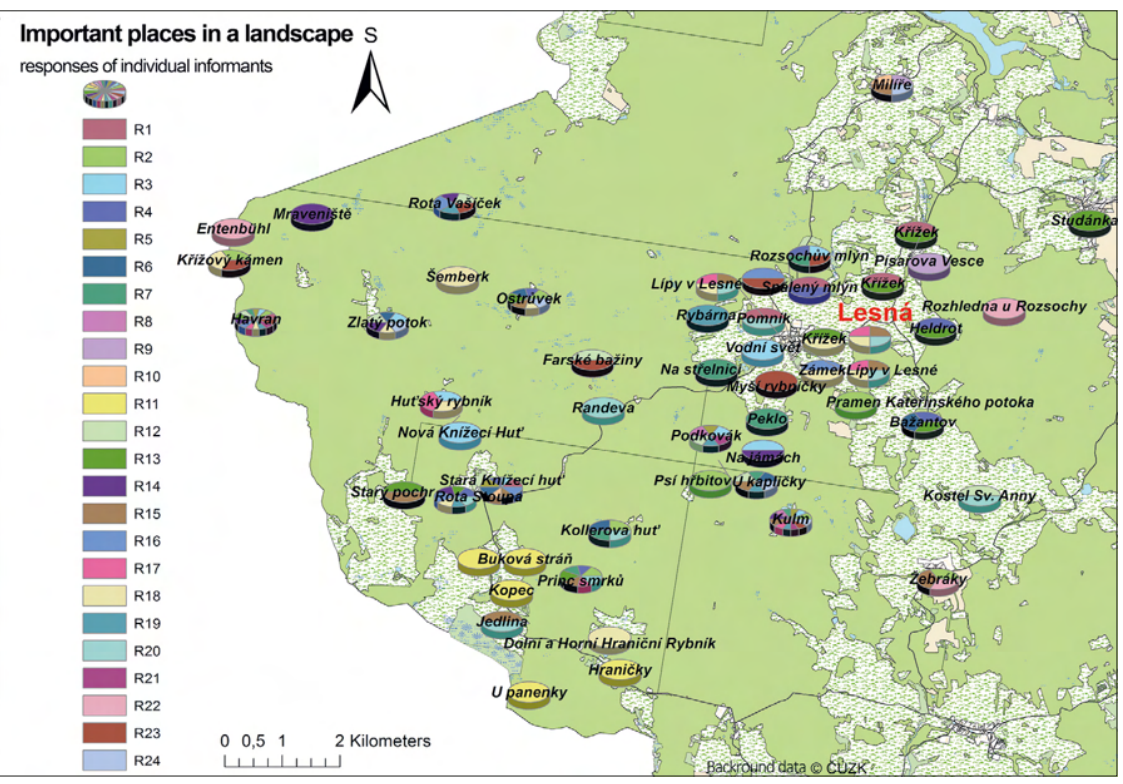

Fig. 7.

An example of a graphic representation of data - important places in a landscape based on the responses of individual informants

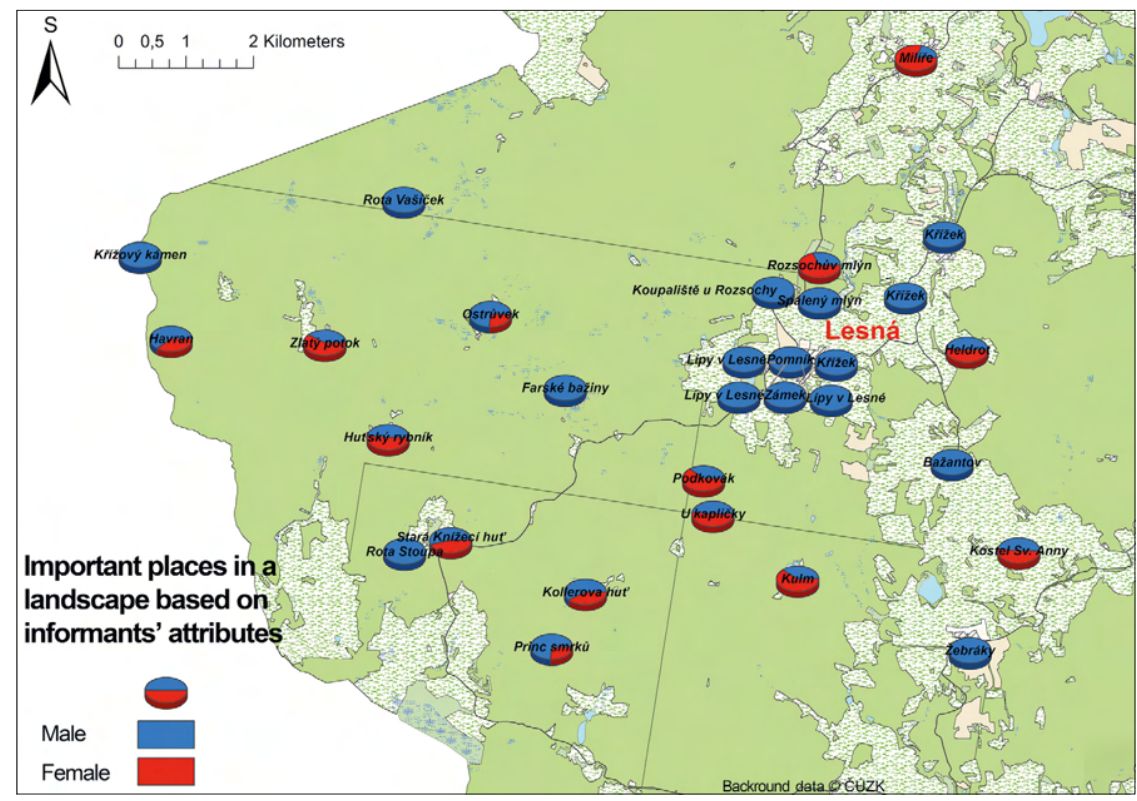

Fig. 8.

An example of a graphic representation of data - important places in a landscape based on informants' attributes (male and female) 
Spatial data visualization allows us to look in a different way at the responses of individual informants. In this case, the figure depicts places based on how the various informants spoke of them, or more precisely, whether these places appeared in their responses or not. In this graphic representation of data we can, among other things, identify isolated informants (in this case, informants R22 and R11) whose responses hardly match those of other informants.

Figure 8 presents places of significance in Lesná and the surrounding area based on the responses of men and women. From the analyzed data set, it is clear that there is a specific set of places listed almost exclusively by men. These places are primarily connected to WWII events or the border area and its protection by the military. Other sites in the Lesná area listed mostly by men included places of generally recognized historical or natural value. On the other hand, women often listed places that are associated with activities usually done by women alone, e.g., places where they pick blueberries, go mushrooming, go for walks, or places associated with their memories or where they play with their children. The location also features a large number of gender-indifferent places. The data visualization in ArcMap helps us think about the gender differences in adopting a landscape, which in this case appear to be significant. GIS in this particular case is applicable not only for the purpose of data visualization, but is also helpful in their interpretation, e.g., in relation to the collectively adopted places displaying gender identities or the

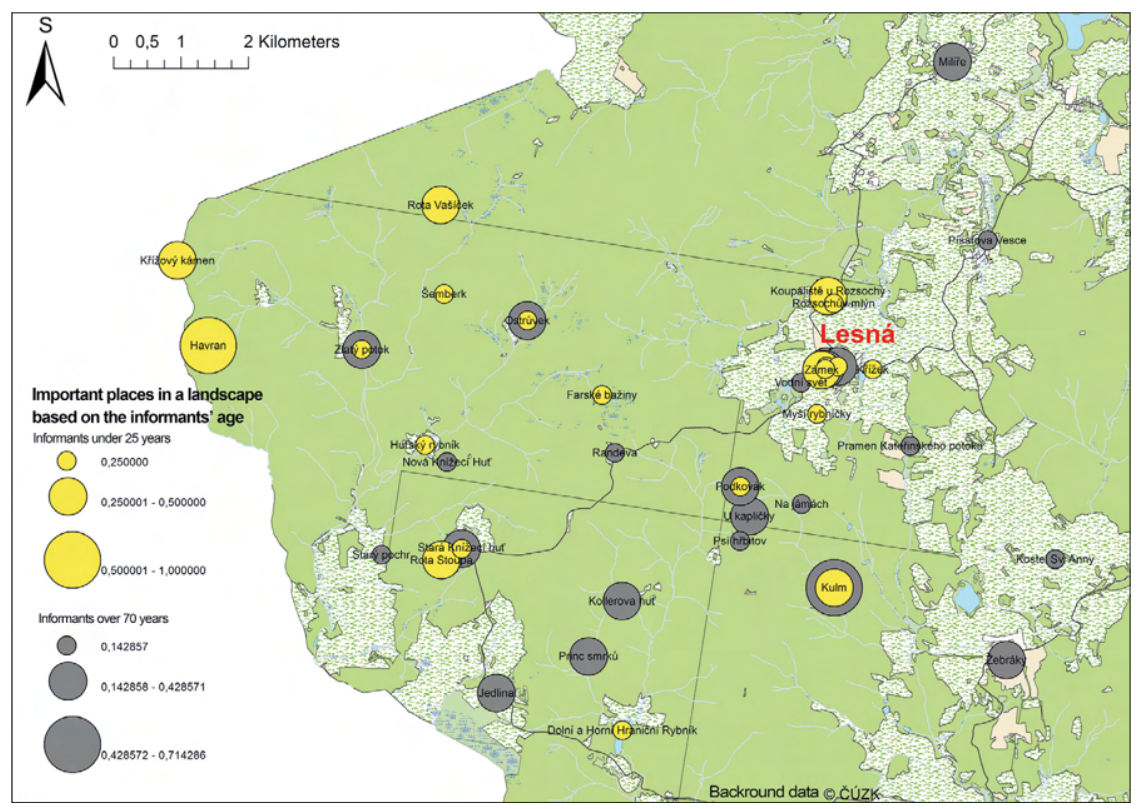

Fig. 9.

An example of a graphic representation of data - important places in a landscape based on the informants' attributes (age) 


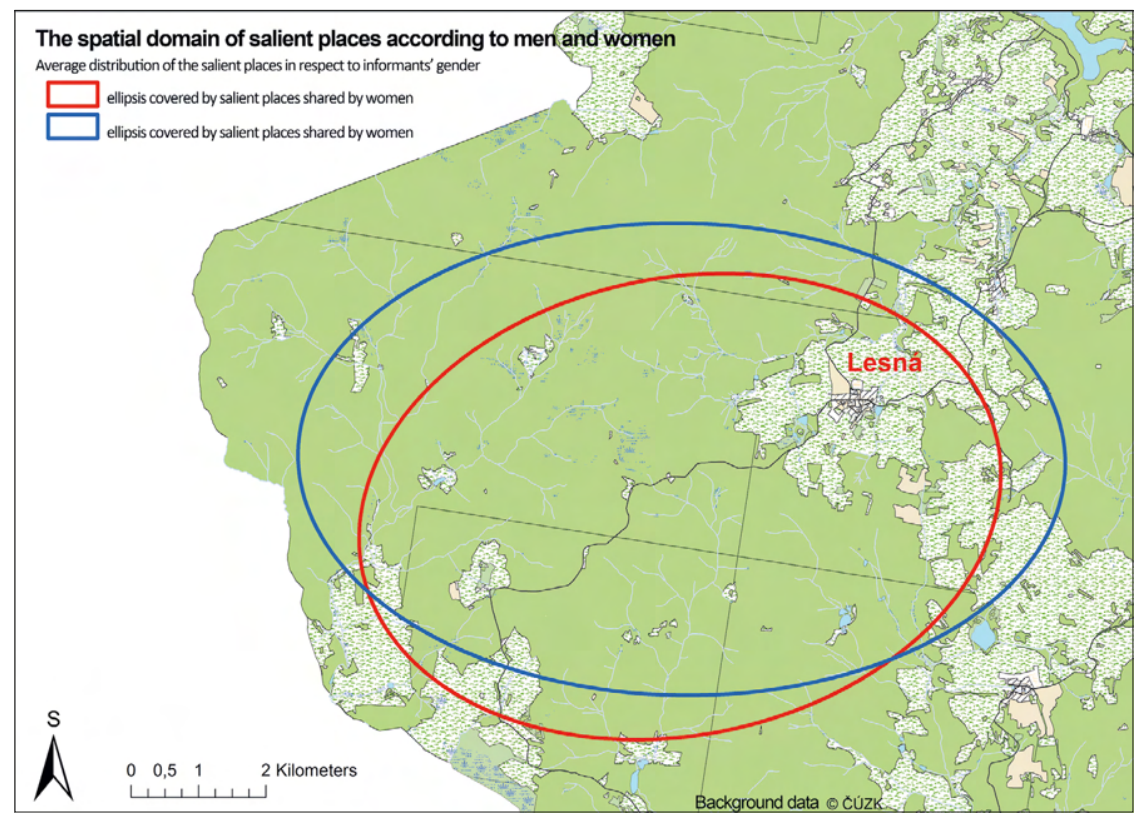

Fig. 10

The spatial domain of salient places according to men and women

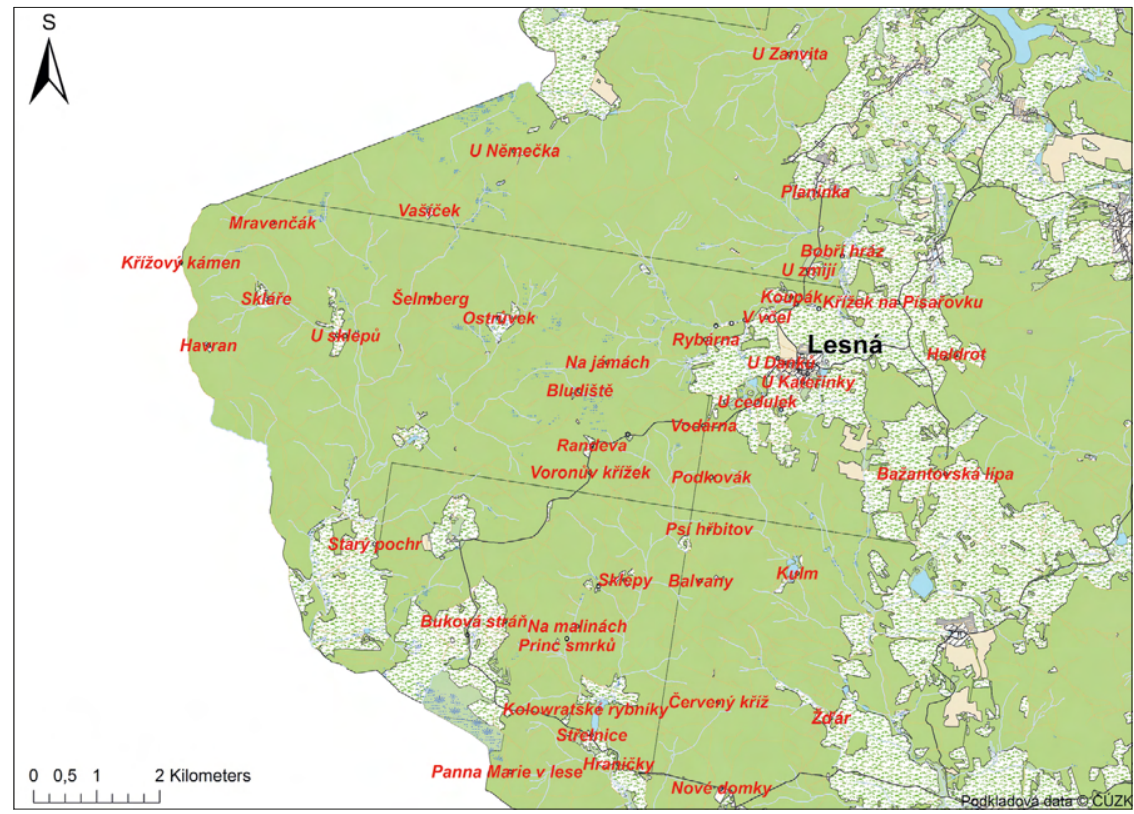

Fig. 11.

Commonly used minor place-names - the map depicts the names of places for which there is agreement by a minimum of 2 informants and which could be localized in the landscape 
identification of gender-indifferent places that are part of a jointly shared vision of a landscape (see Zíková, Fatková 2014).

ArcMap allows data to be further visualized in connection with various attributes, for example, the informants' age (see Fig. 9), their occupation, place of birth, etc. These options provide us with a spatial view of acquired data, allows us to ask new questions and further interpret the acquired data.

Selected tools of the ArcMap 10 software can also serve for the purpose of data processing and their subsequent interpretation. When analyzing places of significance in a landscape, the Directional Distribution tool can create a spatial domain of salient places from the male or female point of view (see Fig. 10), with the resulting ellipsis taking into account the average distribution of the places of significance in space and also taking into account the salience of the place derived from its frequency in responses based on the informants' gender. This graphic representation of data makes it clear that with respect to this case, there is a surprisingly high level of consensus between male and female respondents - there are no major differences between men and women in terms of the distribution of shared places.

ArcMap also makes it possible to work with a variety of other types of data which were collected, for example, using less formalized methods (semi-structured or unstructured interviews, participant observation, guided tours, etc.). Figure 11 displays on a map current minor place-names that were used during interviews with individual informants.

\section{Discussion}

The advantage of using GIS to process ethnographic data of a spatial nature is undoubtedly the possibility of visual presentation of the data, which can serve, for example, for the purpose of revising existing research methodology or as the basis for subsequent individual or group discussions with informants about the data. Data visualization also offers other possibilities, particularly in the area of popularization of research results (in the case of our research, these techniques proved to be suitable tools to generate material for exhibition purposes) and applied social science research, in which the research contracting authority may find spatial visualization of data a more suitable form of presenting research results than a research report or a mere presentation of data. In this respect, suitably visualized data can be useful when it comes to the application of scientific discoveries in practice, e.g., in presentations of proposals of prospective developmental measures to public policy makers, representatives of state administration, memory institutions, etc., as it makes the outcomes of academic research easier to understand and more structured, they have a greater impact and can be incorporated into applied practice more easily (comp. Aldenderfer, Maschner 1996; Willigen 2002; Matthews et al. 2006). 


\section{Conclusion}

Using the techniques of formalized interviewing, it is possible to create a cognitive model of an adopted landscape from the actors' point of view. By analyzing individual components of a given semantic domain (utilizing the ANTHROPAC 4.0 software application), a model of salient places in a landscape of the observed population can be created as a unit of shared group consensus. The cultural domain of shared places of significance represents collectively shared ideas of the participants which are manifested in space (creating so-called sites of memory) and become a field for symbolizing a local identity. The aforementioned examples indicated how, for the purpose of the local actors' perception of the landscape, researchers can utilize visualization and GIS tools (in our case, ArcMAP 10), which, although considered a domain of formalist approaches, help map out spatial characteristics even at a symbolic level, which does not necessarily need to overlap with geographic borders and may exhibit a high degree of variability and fluidity. Using GIS tools, it is possible to develop a model of which places in the landscape are viewed as important in the collective memory of its residents, and how the choice of certain landscape components transforms in relation to the informants' other characteristics.

In this context, it is important to realize that the presented examples are based on the analytical stage of the research, which needs to be followed by an interpretation stage. Within the data interpretation stage, it is also necessary to place great emphasis on other findings acquired using less formalized methods (semi-standardized and non-standardized interviews, participant observation, etc.). Data visualization and their graphic representation in space using one of the GIS tools offers us, among other things, a useful methodological tool providing hindsight of the data themselves and their production - data visualization generates new questions, connections and suggestions for interpretation as well as further research; the overlap of analyses offers a new point of view and different possibilities of interpretation, which other methods and techniques based primarily on textual analyses cannot provide. In this respect, it can be assumed that the analytical potential of GIS for qualitative ethnographic research is significant and not fully utilized.

Relevant interpretation and calibration of data requires their triangulation (data collection using various types of qualitative and quantitative methods) or the bricolage approach, which in the given case is a necessity, as the maximum potential of GIS for ethnographic research can be achieved only through a combination of variously formalized techniques and methods (from unstructured to structured ones) within data production and their analysis and interpretation. 


\section{Bibliography}

Aldenderfer, M., Maschner, H.D.G. (1996). Anthropology, Space, and Geographic Information Systems. NewYork, Oxford: Oxford University Press.

Analytic Technologies. Social Network Analysis Software - Cultural Domain Analysis Software: http:// www.analytictech.com/anthropac/anthropac.htm.

Balée, W., Nolan, J.M. (2019). Freelisting as a Tool for Assessing Cognitive Realities of Landscape Transformation. In: Ch. Isendahl, D. Stump (eds.), The Oxford Handbook of Historical Ecology and Applied Archaeology (p. 366). Oxford: Oxford University Press.

Becková, A. (2015). Kam to patří? Odpad perspektivou kognitivní antropologie. Master thesis University of West Bohemia. Obtained from: https://otik.uk.zcu.cz/bitstream/11025/19228/1/ DP_Beckova_2014.pdf.

Bernard, R.H (2006). Research Methods in Anthropology: Qualitative and Quantitative Approaches Lanham: Rowman \& Littlefield Publishers.

Bieling, C., Plieninger, T., Pirker, H., Vogl, C.R. (2014). Linkages Between Landscapes and Human WellBeing: An Empirical Exploration with Short Interviews. Ecological Economics, 105, 19-30.

Borgatti, S.P. (1994). Cultural Domain Analysis. Journal of Quantitative Anthropology, 4(4), 261-278

Borgatti, S.P. (2015). Software Review: FLAME (Version 1.1). Field Methods, 2(2), 199-205

Borgatti, S.P., Everett, M.G. (2000). Models of Core/Periphery Structures. Social networks, 21(4), 375-395.

Brennan-Horley, C., Luckman, S., Gibson, C., Willoughby-Smith, J. (2010). GIS, Ethnography, and Cultural Research: Putting Maps Back into Ethnographic Mapping. The Information Society, 26, 92-103.

Brewer, D.D. (2002). Supplementary Interviewing Techniques to Maximize Output in Free Listing Tasks Field Methods 14, 108-118

Carr, N. (2010). The Shallows: How the Internet Is Changing the Way we Think, Read and Remember. Atlantic Books Ltd.

Ceccato, V., Haining, R. (2004). Crime in Border Regions: The Scandinavian case of Öresund, 1998-2001. Annals of the Association of American Geographers, 94(4), 807-826.

Chapin, M., Lamb, Z., Threlkeld, B. (2005). Mapping Indigenous Lands. Annual Review of Anthropology, 34, 619-638.

D’Andrade, R.G. (1995). The Development of Cognitive Anthropology. Cambridge University Press.

Fagerholm, N., Martín-López, B., Torralba, M., Oteros-Rozas, E., Lechner, A.M., Bieling, C., Plieninger, T. (2020). Perceived Contributions of Multifunctional Landscapes to Human Well-Being: Evidence from 13 European sites. People and Nature, 2(1), 217-234.

Fatková, G. (2015) Data v antropologii I.: Strukturované metody vytváření dat. In: : P. Krištuf, T.Zíková et al. (eds.), Výzkum krajiny: vybrané antropologické a archeologické metody (pp. 30-38). Pilsen: Západočeská univerzita v PIzni.

Fatková, G., Zíková, T. (2013). Tenkrát na "čáře": lidé, věci a čas vepsaní do pohraniční krajiny: případ západočeské obce Lesná. In: J. Stočes, E. Mušková (eds.), Tenkrát na západě (Čech). Kapitoly z dějin kultury a každodennosti Plzně a Plzeňského kraje (pp. 225-238). Pilsen: Západočeská univerzita v Plzni.

Fatková, G., Zíková, T. (2014). Lokální identita a pamět krajiny: významné krajinné komponenty v perspektivě aktérů. Národopisná revue, 3, 116-129.

Gravlee, C.C. (1998). The Uses and Limitations of Free Listing in Ethnographic Research. Research Methods in Cognitive Anthropology. Gainesville: Dept. of Anthropology, University of Florida. Obtained from: http://gravlee.org/ang6930/freelists.htm. 
Gravlee, C.C. (2005). Ethnic Classification in Southeastern Puerto Rico: The Cultural Model of "Color", Social Forces, 83(3), 949-970.

Keddem, S., Barg, F.K., Glanz, K., Jackson, T., Green, S., George, M. (2015). Mapping the Urban Asthma Experience: Using Qualitative GIS to Understand Contextual Factors Affecting Asthma Control. Social science \& medicine, 140, 9-17.

Komossa, F., Wartmann, F.M., Kienast, F., Verburg, P.H. (2020). Comparing Outdoor Recreation Preferences in Peri-Urban Landscapes Using Different Data Gathering Methods. Landscape and Urban Planning, 199, 1-10.

Lakoff, G. (1990). Ženy, oheň a nebezpečné věci: co kategorie vypovídají o naší mysli. Prague: Triáda.

Matthews, S.A., Detwiler, J.E., Burton, L.M. (2006). Geo-ethnography: Coupling Geographic Information Analysis Techniques with Ethnographic Methods. Urban Research, Cartographica, 40(4), 75-90.

Quinlan, M. (2005). Considerations for Collecting Freelists in the Field: Examples from Ethobotany Field Methods, 17(3), 219-234.

Sorts, P. (2017). An Introduction to Cultural Domain Analysis in Food Research. Food Culture: Anthropology, Linguistics and Food Studies, 2, 159.

Stara, K., Tsiakiris, R., Wong, J.L. (2015). Valuing Trees in a Changing Cultural Landscape: a Case Study from Northwestern Greece. Human Ecology, 43(1), 153-167.

Šlehoferová, T. (2015) Antropologická data v prostředí Anthropac a GIS. In: P. Krištuf, T.Zíková et al. (eds.), Výzkum krajiny: vybrané antropologické a archeologické metody (pp. 103-112). Pilsen: Západočeská univerzita v PIzni.

Toušek, L. (2012). Vybrané aspekty metodologie aplikované antropologie, In: T. Hirt (ed.), Vybrané kapitoly z aplikované sociální antropologie (pp. 25-106). Pilsen: Západočeská univerzita v Plzni.

Wartmann, F.M., Egorova, E., Derungs, C., Mark, D.M., Purves, R.S. (2015). More Than a List: What Outdoor Free Listings of Landscape Categories Reveal About Commonsense Geographic Concepts and Memory Search Strategies. In: International Conference on Spatial Information Theory (pp. 224-243). Springer.

Weller, S.C. (2007). Cultural Consensus Theory: Applications and Frequently Asked Questions. Field methods, 19(4), 339-368.

Willigen, J.van. (2002). Applied Anthropology: An Introduction (Third Edition). Connecticut, London: Bergin \& Garvey.

\section{List of Figures}

Fig. 1. A view of data acquired from freelisting following their import into the ANTHROPAC software. Prepared by G. Fatková, T. Šlehoferová.

Fig 2. Similarity matrix in Anthropac. Prepared by G. Fatková, T. Šlehoferová.

Fig. 3. Visualization of data in a core-periphery structure. Prepared by G. Fatková, T.Šlehoferová.

Fig. 4. A localization of researched villages Lesná and Bušovice. Prepared by G. Fatková, T. Šlehoferová

Fig. 5. An example of a graphic representation of data - important places in a landscape based on frequency (excl. the value of 1). Prepared by G. Fatková, T. Šlehoferová.

Fig. 6 . An example of a graphic representation of data - important places in a landscape based on the salience index (excl. the value of 1). Prepared by G. Fatková, T. Šlehoferová.

Fig.7. An example of a graphic representation of data - important places in a landscape based on the responses of individual informants. Prepared by G. Fatková, T. Šlehoferová. 
Fig. 8. An example of a graphic representation of data - important places in a landscape based on informants' attributes (male and female). Prepared by G. Fatková, T. Šlehoferová.

Fig. 9. An example of a graphic representation of data - important places in a landscape based on the informants' attributes (age). Prepared by G. Fatková, T. Šlehoferová.

Fig. 10. The spatial domain of salient places according to men and women. Prepared by G. Fatková, T. Šlehoferová.

Fig. 11. Commonly used minor place-names - the map depicts the names of places for which there is agreement by a minimum of 2 informants and which could be localized in the landscape. Prepared by G. Fatková, T. Šlehoferová.

\section{Summary}

In this article, we present how, using the example of research studies connected with the perception of a landscape, some structured methods of data production used primarily in cognitive anthropology can be applied along with the possibilities of data analysis visualization using geographic information systems. We show the process of working with data gained by qualitative techniques and transferred, using semantic domain analysis, to the GIS interface, and outline the room for interpretation opened up by such a multi-level approach using various tools. Although we subjected the described procedures to pilot verification in our own research, the connection of the presented methodological approaches is still open to scientific discussion and, above all, to further experimentation.

Keywords: landscape, structured methods of data production, GIS (geographic information system), ethnographic research

\section{Streszczenie}

W artykule prezentujemy zastosowanie niektórych strukturyzowanych metod wytwarzania danych, używanych przede wszystkim w antropologii kognitywnej, równolegle z metodami wizualizacji danych za pomocą systemów informacji geograficznej (GIS) na przykładzie badań związanych z percepcją krajobrazu. Omawiamy proces opracowywania danych uzyskanych techniką jakościową i przeniesionych za pomocą analizy domen semantycznych do interfejsu GIS oraz definiujemy możliwości interpretacyjne, jakich dostarcza zastosowanie tak wielopoziomowego podejścia i zróżnicowanych narzędzi. Opisane w artykule procedury zostały wstępnie zweryfikowane w badaniach własnych, lecz powiązania między opisywanymi w artykule podejściami metodologicznymi powinny stanowić przedmiot dalszej dyskusji naukowej, a przede wszystkim weryfikacji doświadczalnej.

Słowa klucze: krajobraz, strukturyzowane metody wytwarzania danych, system informacji geograficznej (GIS), badania etnograficzne 
